\title{
Large-scale temperature and salinity changes in the upper Canadian Basin of the Arctic Ocean at a time of a drastic Arctic Oscillation inversion
}

\author{
P. Bourgain ${ }^{1}$, J. C. Gascard ${ }^{1}$, J. Shi ${ }^{2}$, and J. Zhao ${ }^{2}$ \\ ${ }^{1}$ Laboratoire d'océanographie et du climat: expérimentations et approches numériques (LOCEAN) - UMR 7159, \\ Université Pierre et Marie Curie, Paris, France \\ ${ }^{2}$ College of Physical and Environmental Oceanography, Ocean University of China, Qingdao, China
}

Correspondence to: P. Bourgain (pascaline.bourgain@locean-ipsl.upmc.fr)

Received: 2 April 2012 - Published in Ocean Sci. Discuss.: 10 May 2012

Revised: 8 February 2013 - Accepted: 26 February 2013 - Published: 10 April 2013

\begin{abstract}
Between 2008 and 2010, the Arctic Oscillation index over Arctic regions shifted from positive values corresponding to more cyclonic conditions prevailing during the 4th International Polar Year (IPY) period (2007-2008) to extremely negative values corresponding to strong anticyclonic conditions in 2010. In this context, we investigated the recent large-scale evolution of the upper western Arctic Ocean, based on temperature and salinity summertime observations collected during icebreaker campaigns and from icetethered profilers (ITPs) drifting across the region in 2008 and 2010. Particularly, we focused on (1) the freshwater content which was extensively studied during previous years, (2) the near-surface temperature maximum due to incoming solar radiation, and (3) the water masses advected from the Pacific Ocean into the Arctic Ocean. The observations revealed a freshwater content change in the Canadian Basin during this time period. South of $80^{\circ} \mathrm{N}$, the freshwater content increased, while north of $80^{\circ} \mathrm{N}$, less freshening occurred in 2010 compared to 2008 . This was more likely due to the strong anticyclonicity characteristic of a low AO index mode that enhanced both a wind-generated Ekman pumping in the Beaufort Gyre and a possible diversion of the Siberian River runoff toward the Eurasian Basin at the same time. The nearsurface temperature maximum due to incoming solar radiation was almost $1{ }^{\circ} \mathrm{C}$ colder in the southern Canada Basin (south of $75^{\circ} \mathrm{N}$ ) in 2010 compared to 2008 , which contrasted with the positive trend observed during previous years. This was more likely due to higher summer sea ice concentration in 2010 compared to 2008 in that region, and surface
\end{abstract}

albedo feedback reflecting more sun radiation back in space. The Pacific water $(\mathrm{PaW})$ was also subjected to strong spatial and temporal variability between 2008 and 2010. In the Canada Basin, both summer and winter PaW signatures were stronger between $75^{\circ} \mathrm{N}$ and $80^{\circ} \mathrm{N}$. This was more likely due to a strong recirculation within the Beaufort Gyre. In contrast, south of $75^{\circ} \mathrm{N}$, the cooling and warming of the summer and winter PaW, respectively, suggest that either the $\mathrm{PaW}$ was less present in 2010 than in 2008 in this region, and/or the $\mathrm{PaW}$ was older in 2010 than in 2008. In addition, in the vicinity of the Chukchi Sea, both summer and winter PaW were significantly warmer in 2010 than in 2008 , as a consequence of a general warming trend of the $\mathrm{PaW}$ entering in the deep Arctic Ocean as of 2008.

\section{Introduction}

The sea level pressure (SLP) in the Arctic is characterized by a high pressure over the Beaufort Sea, known as the Beaufort Sea High, and a low pressure extending from Iceland to the Kara Sea. The first mode of the Northern Hemisphere SLP variability is the Arctic Oscillation (AO; Thompson and Wallace, 1998) that can be interpreted as a mass exchange between the Arctic Ocean and the mid-latitudes (Stroeve et al., 2011). The AO regime is quantified by an index constructed by projecting the monthly mean $1000 \mathrm{hPa}$ height anomalies poleward of $20^{\circ} \mathrm{N}$ onto the leading empirical orthogonal function mode of the SLP. The AO index oscillates between 
a positive and a negative phase characterized by anomalously low and high SLP, respectively, over the Arctic.

Previous studies considered the impact of the AO on sea ice and water mass variability in the Arctic Ocean and more specifically in the Canadian Basin (Proshutinsky and Johnson, 1997; Rigor and Wallace, 2004; Kwok, 2000; Steele et al., 2004). During a negative AO, the strengthened anticyclonic Beaufort Gyre aligns the principal axis of the Transpolar Drift with the Lomonosov Ridge. As a result, there is a strong recirculation within the Beaufort Gyre, bringing $\mathrm{PaW}$ to the southern Beaufort Gyre (Steele et al., 2004); the intensification of the Ekman pumping of the gyreenhances freshwater accumulation (Proshutinsky et al., 2002, 2009; McPhee et al., 2009). In addition, the Siberian River runoff, driven by the Transpolar Drift, is diverted towards the Amundsen Basin rather than towards the Makarov Basin, which decreases the freshwater content of the Makarov Basin (Steele and Boyd, 1998).

Recently, the Arctic atmospheric forcing changed drastically. Following a period of a positive AO phase ending in 2008, the winter (December-January-February) average of the standardized AO index dropped from 0.86 in 2008 to -3.42 in 2010, reaching the lowest value since 1950 (see Fig. 1). This recent evolution of the AO represents one of the most abrupt shifts during the last decades. It is comparable in magnitude (but opposite in sign) to the shift observed in the late 1980s, which was responsible for some major changes in sea ice advection (Kwok, 2000; Rigor et al., 2002) and oceanic circulation (Dickson et al., 2000) in the Arctic Ocean, with consequences on the Northern Atlantic deep convection (Gerdes et al., 2008). In such a context, what could be the response of the upper Arctic Ocean to the drastic increase of the atmospheric anticyclonicity that occurred between 2008 and 2010?

We propose an analysis of the recent evolution of the upper ocean water masses in the Canadian Basin, where the exchanges between the ocean and the atmosphere are particularly strong due to reduced Arctic summer sea ice cover (Shimada et al., 2006). Based on observations collected during the summers 2008 and 2010, we will analyse the shortterm variability of the main oceanic features of the Canadian Basin upper ocean in light of the recent changes in the atmosphere and in the sea ice.

\section{Data and method}

\subsection{Study area}

Here, we follow Steele et al. (2011) in defining the Canadian Basin as extending from the Lomonosov Ridge eastward along the East Siberian, Alaskan and Canadian coasts. Based on the bathymetry, the Canadian Basin is subdivided into different areas (see Fig. 2). The deep basins (1000 m to $4000 \mathrm{~m}$ ) are composed of the Canada Abyssal Plain or Canada Basin

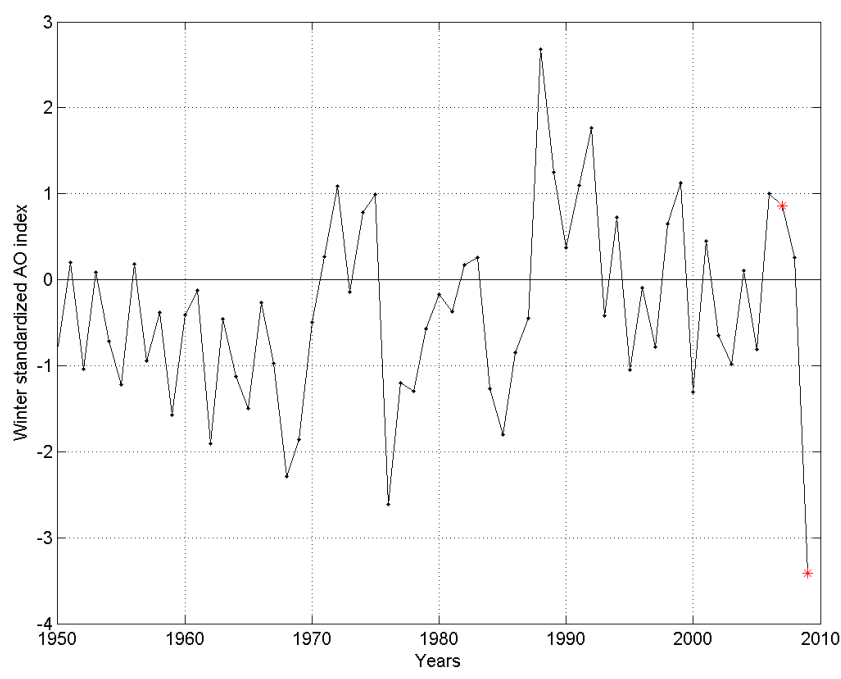

Fig. 1. Time series of the AO index, averaged for December through February, for the period 1950-2010, normalized by the standard deviation of the monthly AO index from 1979-2000. Data were obtained at www.ncep.noaa.gov/. Years 2008 and 2010 are indicated in red.

$(\mathrm{CaB})$ and the Mendeleyev Abyssal Plain (MAP). Therefore the Canada Basin is a subregion of the Canadian Basin. These deep basins are separated from the Makarov Basin (MaB) by the Alpha Ridge (AR) on the east and by the Mendeleyev Ridge (MR) on the West. The vast $(\sim 800 \mathrm{~km}$ in meridional extent) and shallow $(<100 \mathrm{~m})$ Chukchi Shelf is edged by a continental slope in the North and an abrupt shelfbreak in the north-east. The Chukchi Borderland (ChB), considered as a mid-depth $(1000 \mathrm{~m})$ extension of the Chukchi Shelf, is a complex area composed by the Chukchi Abyssal Plain (CAP), the $200 \mathrm{~km}$-long Chukchi Plateau (CP) separated from the Chukchi Shelf by the Chukchi Gap, and the Northwind Ridge (NR). One of the possible gateways for the Chukchi Shelf waters to enter the deep Arctic Ocean is north of the Alaskan coast, through the Barrow Canyon (BA area). Close to the Canadian Archipelago, the Mackenzie River provides freshwater to the shelves (MK area).

In the following, we will focus our analysis on the 120$180^{\circ} \mathrm{W}$ area of the Canadian Basin divided into five main areas (each area boundary is located by an ellipse in Fig. 2): the Chukchi Borderland (ChB including the $\mathrm{CP}$, the NR and the CAP), the Barrow Canyon region (BA) and the Mackenzie River region (MK) for the relatively shallow regions, and the Canada Basin $(\mathrm{CaB})$ and the Mendeleyev Abyssal Plain (MAP) for the deep basins. These five areas cover the main regions of the Canadian Basin of the Arctic Ocean, providing some representation of the overall situation in this basin. Note that the regional means will be sometimes associated with large standard deviations due to the heterogeneity of a variable inside a same region. 


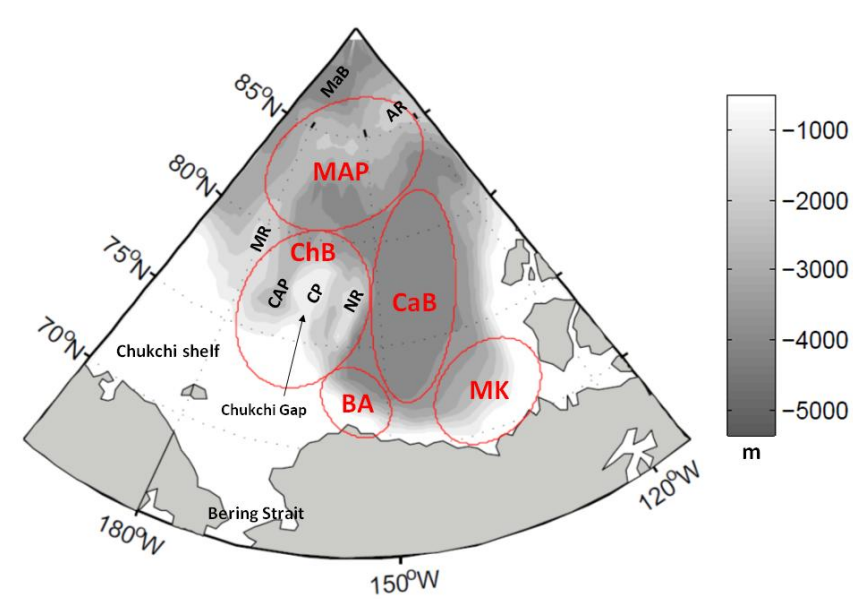

Fig. 2. Bathymetry and main topographic features of the Canadian Basin. CP stands for Chukchi Plateau, NR for Northwind Ridge, and CAP for Chukchi Abyssal Plain. AR and MR stand for Alpha Ridge and Mendeleyev Ridge, respectively, and MaB stands for the Makarov Basin. The ellipses correspond to the five subdivisions of the area chosen for this study: the Chukchi Borderland ( $\mathrm{ChB}$ including the $\mathrm{CP}$, the NR and the $\mathrm{CAP}$ ), the Barrow Canyon region (BA), the Mackenzie River region (MK), the Canada Basin (CaB), the Mendeleyev Abyssal Plain (MAP).

\subsection{Data}

\subsubsection{Atmospheric data}

Daily fields of SLP and air temperature at $925 \mathrm{hPa}$ (AT925) were obtained from the National Center for Atmospheric Research/National Centers for Environmental Prediction (NCAR/ NCEP) reanalysis data, computed on $2.5^{\circ} \times 2.5^{\circ}$ grid (Kalnay et al., 1996). The original data are available from the RDA (http://dss.ucar.edu) in data set number ds090.0. We focus on the winter months (December through February), when the AO variability is the largest, to obtain the winter average SLP and AT925 maps over the Arctic in 2008 and 2010.

\subsubsection{Sea ice data}

Daily sea ice concentrations were obtained from the Japanese Advanced Microwave Scanning Radiometer for the Earth Observing System (AMSR-E) that provides the highest resolution satellite passive-microwave imagery available, with spatial resolutions of approximately $6 \times 4 \mathrm{~km}$ at $89 \mathrm{GHz}$ (Spreen et al., 2008). The data are free and available at http://www.iup.uni-bremen.de. We used these data to construct mean sea ice concentration maps on the summertime period (July-August-September), both in 2008 and 2010.

\subsubsection{CTD data}

A high number of CTD (conductivity-temperature-depth) measurements were collected during the CHINARE (Chi- nese National Arctic Research Expedition) 2008 (1 August-8 September) and 2010 (1 July-20 September) campaigns on board the Chinese icebreaker Xuelong; 88 and 143 CTD stations were completed in 2008 and 2010, respectively, in the Bering Sea, the Chukchi Sea and in the Arctic Ocean. In this paper, we will focus on CTD stations realized north of $70^{\circ} \mathrm{N}$ and deeper than $50 \mathrm{dbar}$, which correspond to 88 CTD stations both in 2008 and 2010. For both campaigns, the CTD was a SBE911 mounted on a 24-bottles rosette sampler with $10 \mathrm{~L}$ Niskin bottles. Accuracy of temperature and salinity measurement was $0.001{ }^{\circ} \mathrm{C}$ and 0.001 psu respectively. The SBE911 CTD was calibrated before and after the campaigns. In 2010, the summer ice conditions in the northern Canadian Basin were light and the icebreaker was able to go as far north as $88.4^{\circ} \mathrm{N}$, compared to $85.4^{\circ} \mathrm{N}$ in 2008 .

The data set collected during CHINARE campaigns in the Canada Basin in summers 2008 and 2010 was completed with data collected in the same area (the $120-180^{\circ} \mathrm{W}$ longitude range), on the same time period (1 July-30 September), during other icebreaker campaigns (Table 1 and Fig. 3) or thanks to autonomous drifting buoys (see Sect. 2.2.4).

We used the data collected between 1 July and 30 September 2010 during the R/V Polarstern ARK XXIII/3 campaign (the cruise was led between 12 August 2008 and 17 October 2008; Rabe et al., 2011), and during two CCGS Louis $S$. St-Laurent (LSSL) campaigns (led between 17 July and 21 August 2008, and 15 September and 15 October 2010). Both R/V Polarstern and $L S S L$ cruises used a SBE911+ CTD system with accuracies of $0.001{ }^{\circ} \mathrm{C}$ and $0.001 \mathrm{psu}$.

\subsubsection{Ice-tethered profiler data}

In addition, we also used data collected by drifting buoys, the ice-tethered profilers (ITPs, level 3 data), deployed by the Woods Hole Oceanographic Institute. The ITPs collected up to four profiles per day and we used the data with the highest level of process (level 3), which were collected in summers 2008 and 2010 in the $120-180^{\circ} \mathrm{W}$ longitude range. The corresponding ITPs are: $6,8,11,13,18,22,23,25,27,28,33$ and 35 . The measurement error for temperature and salinity from level 3 data is estimated at $0.001{ }^{\circ} \mathrm{C}$ and $0.005 \mathrm{psu}$ respectively, the vertical resolution is $1 \mathrm{~m}$. ITP data are available online at http://www.whoi.edu/itp.

\subsection{Methodology}

After removing outliers, the data set, extending from the near-surface down to 1000 decibar (dbar) level, was interpolated each $1 \mathrm{dbar}$. The density and the potential temperature were calculated using UNESCO 1983 tables (Fofonoff and Millard, 1983).

We used the Kriging interpolation method to construct spatial maps on a $1^{\circ}$ longitude $\times 0.5^{\circ}$ latitude grid of several parameters first estimated from original $T$ and $S$ profiles. The Kriging method is a geostatistical technique to interpolate 
Table 1. Number of CTD stations by year and source used for this study, on summertime (from 1 July to 30 September), in the region $120-180^{\circ} \mathrm{W}$ of the Arctic Ocean.

\begin{tabular}{llllll}
\hline $\begin{array}{l}\text { Source } \\
\text { Year }\end{array}$ & CHINARE & ITPs & $\begin{array}{l}\text { R/V } \\
\text { Polarstern }\end{array}$ & CCGS-LSSL & TOTAL \\
\hline 2008 & 88 & $\begin{array}{l}\text { ITPs no. 6,8,11,13,18,22,23,25,27,28 } \\
812\end{array}$ & 12 & 72 & 984 \\
2010 & 88 & $\begin{array}{l}\text { ITPs no. 22,23,33,35 } \\
184\end{array}$ & 0 & 72 & 344 \\
& & & & \\
\hline
\end{tabular}

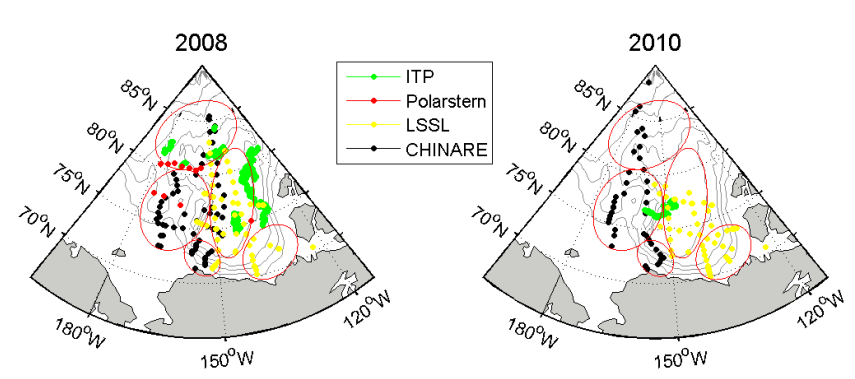

Fig. 3. Location and source of both CTD and ITP data for years 2008 (left) and 2010 (right). The ellipses correspond to the subdivision chosen for the Canadian Basin.

the value of a random field observations at nearby locations, which is an improvement on all other interpolation methods because it minimizes error covariance. We chose the ten closest points within a $300 \mathrm{~km}$-radius to be the Kriging interpolation neighbourhood. The radius was determined by the range of the variogram (Krige, 1951 and Matheron, 1963).

In this paper, we focused on large-scale changes from 2008 to 2010. However, because some of the data were collected either at the beginning or at the end of the summer season (for instance, the oceanographic observations originating from LSSL 2008 and LSSL 2010 cruises occurred JulyAugust and in September, respectively), seasonal variability might intervene in the differences observed from one year to another.

\section{Atmospheric and sea ice conditions in 2008 and 2010}

\subsection{Atmospheric conditions}

As expected, the strong shift in the AO index that occurred between 2008 and 2010 was associated with a change in the Arctic SLP field (Fig. 4). The mean winter SLP was larger in 2010 than in 2008 over the Canadian Basin, featuring a stronger Beaufort Sea High, with a maximum of $1024 \mathrm{hPa}$ reached in 2010 against $1018 \mathrm{hPa}$ in 2008 .

In response to the atmospheric forcing shift that enhanced the exchanges of air masses between the Arctic and the midlatitudes in 2010, the mean winter AT925 field reveals a no-
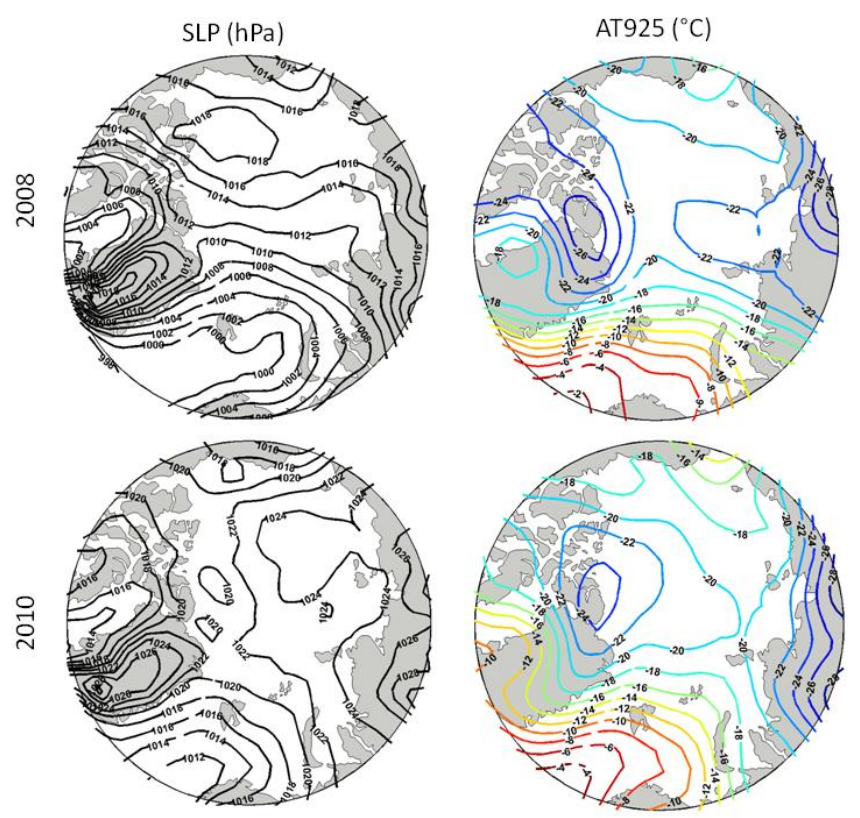

Fig. 4. Mean wintertime (December-January-February) SLP (left) in $\mathrm{hPa}$, and temperature at $925 \mathrm{hPa}$ (right) in degrees Celsius, both in 2008 (top) and 2010 (bottom).

ticeable warming in 2010, especially over Greenland, the Canadian Archipelago and Alaska.

\subsection{Sea ice conditions}

Figure 5 displays the summer sea ice conditions in the Canadian Basin in 2008 and 2010. Noticeable differences between the two years appeared in the southern Canadian Basin with more sea ice in 2010, especially in the $\mathrm{ChB}$ and in the southern $\mathrm{CaB}$, with a large tongue of very high sea ice concentration (about $80 \%$ ) appearing between 70 and $75^{\circ} \mathrm{N}$. When comparing sea ice motion fields from 2009/2010 to the climatology (1979-2009), Stroeve et al. (2011) observed a strengthening of the southward and westward transport of sea ice due to wind forcing along the Canadian Archipelago towards the eastern Beaufort Sea. The sea ice transport was $124 \%$ higher than climatology in this region, explaining the presence of multiyear ice extending from the Beaufort Sea into the Chukchi Sea in 2010. 

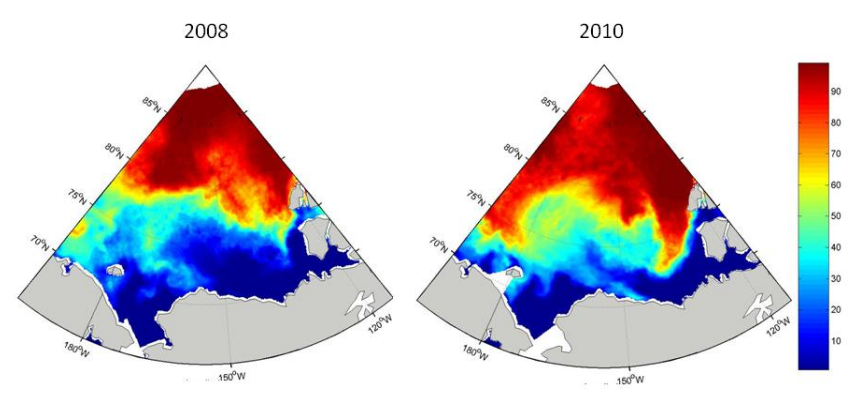

Fig. 5. Mean summer (July, August, September) sea ice concentrations in percent, in 2008 (left) and 2010 (right), obtained from the AMSR-E data.

\section{Regional hydrography and recent changes}

The Canadian Basin water column structure (see Fig. 6) is more complex than in the Eurasian Basin due to the presence of different temperature extrema between the surface mixed layer and the main thermocline. Firstly, located immediately below the surface mixed layer, the near-surface temperature maximum (NSTM) is due to incoming solar radiation (Jackson et al., 2010). Then, the summer Pacific water (SPaW) is located at 50-100 $\mathrm{m}$ depth, in the upper halocline, and finally, the winter Pacific water (WPaW) is located in the middle halocline, above the thermocline, around 150-200 m depth (Coachman and Barnes, 1961). At greater depth (300$500 \mathrm{~m}$ depth), the warm and salty Atlantic waters constitute the main reservoir of heat for the whole Arctic Ocean.

\subsection{The NSTM}

\subsubsection{Background}

Jackson et al. (2010) have shown that the ice-free upper ocean layer being in direct contact with the atmosphere and exposure to incoming solar radiation has the capacity to store heat. A shallow seasonal halocline due to sea ice melt may isolate the surface layer warmed up by incoming solar radiation. This creates a near-surface temperature maximum (NSTM) located typically at depths of 25-35 m (above the summer Pacific water) and at salinities less than 31 psu. This heat can be stored year-round in the Canada Basin if the summer halocline persists throughout the year (Jackson et al., 2010; Steele et al., 2011).

When looking at AIDJEX (Arctic Ice Dynamics Joint Experiment) profiles acquired in 1975, Toole et al. (2010) noticed that there was "virtually no NSTM" in the Canada Basin water column at this time. In the 1990s-2000s, Jackson et al. (2010) observed that the NSTM increased and moved northward and upward from 1993 to 2007. Between 75 and $80^{\circ} \mathrm{N}$, the extreme NSTM values were observed in 2007 (maximum) and in 2003-2004 (minimum), which corresponds to an increasing rate of $0.13^{\circ} \mathrm{C} \mathrm{yr}^{-1}$ from 2004 to 2007. In addition, the NSTM has shoaled by $2.1 \mathrm{~m} \mathrm{yr}^{-1}$
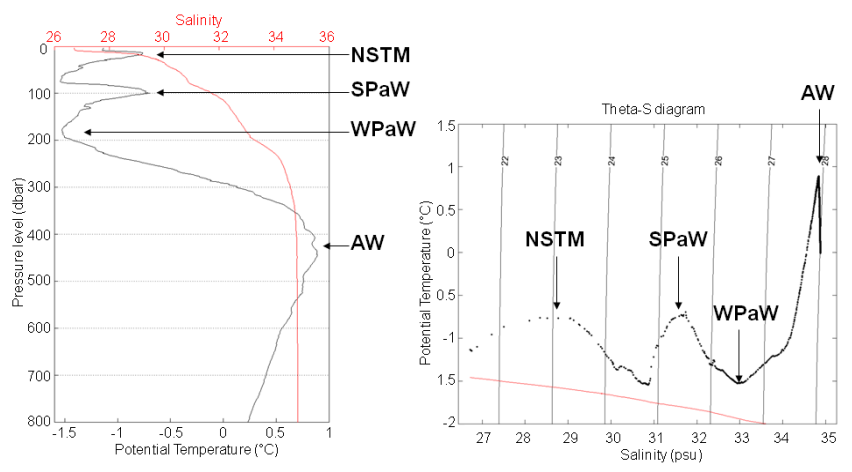

Fig. 6. A typical vertical potential temperature and salinity profile of the study area (left) and the corresponding $\theta S$ diagram (right) with the freezing point indicated in red. The NSTM (near-surface temperature maximum), the SPaW (summer Pacific water), the WPaW (winter Pacific water) and the AW (Atlantic water) are indicated. This profile was recorded in August 2008 during the CHINARE campaign, at location $76.98^{\circ} \mathrm{N}, 146.1^{\circ} \mathrm{W}$.

since 1997, when the NSTM was the deepest at about $33 \mathrm{~m}$ depth, to reach $15 \mathrm{~m}$ depth in 2007 . More recently, Jackson et al. (2012) found that "heat from the NSTM is entrained into the surface mixed layer during winter", highlighting the importance of the NSTM in the sea ice mass balance.

\subsubsection{New results}

Following Jackson et al.'s (2010), we defined the NSTM as the temperature maximum that was nearest to the surface and above $40 \mathrm{dbar}$, with a salinity of less than 31 psu and a temperature at least $0.2^{\circ} \mathrm{C}$ above the freezing temperature. Note that some profiles did not reach the surface and may have not sampled the NSTM for this reason.

We observed in 2008 and 2010 that the highest temperatures were located in the southern Canadian Basin, close to the Alaskan coasts (Fig. 7). In some regions of the northern Canadian Basin, there was no NSTM evidenced (grey areas in Fig. 7). From 2008 to 2010, we observed a general decrease and deepening of the NSTM in the Canadian Basin, south of $80^{\circ} \mathrm{N}$, which contrasts with the situation of the previous years as described by Jackson et al. (2010). For instance, in the $\mathrm{ChB}$, the NSTM decreased by $-0.76 \pm 0.70^{\circ} \mathrm{C}$ and deepened by $4 \pm 7 \mathrm{dbar}$ (Table 2). In the southern $\mathrm{CaB}$, the NSTM was particularly smaller (by more than $1{ }^{\circ} \mathrm{C}$ ) and deeper (by more than $10 \mathrm{dbar}$ ) in 2010 compared to 2008. Note that at some locations in the BA and MK, there was a strong NSTM increase but more data would be needed to confirm it.

One must consider the possibility for the observed NSTM variability to be affected by seasonal variability, in addition to differences between 2008 and 2010, as the observations were collected between 1 July and 30 September, which is a time period long enough to capture the cooling 
Table 2. Temporal evolution of the NSTM characteristics in the five areas between 2008 and 2010. Note that the average value of NSTM being calculated on a different number of points in 2008 and 2010, the average value of NSTM (2010)-NSTM (2008) is not equal to the difference between the average value of NSTM (2010) and the average value of NSTM (2008). This remark stands for the other variables.

\begin{tabular}{lrrrrrrr}
\hline & \multicolumn{3}{c}{ Temperature $\left({ }^{\circ} \mathrm{C}\right)$} & & \multicolumn{3}{c}{ Depth (dbar) } \\
\cline { 2 - 3 } \cline { 7 - 8 } & 2008 & 2010 & $2010-2008$ & & 2008 & 2010 & $2010-2008$ \\
\hline MAP & $-1.43 \times 0.19$ & $-1.67 \times 0.12$ & $-0.23 \times 0.21$ & & $24 \times 3$ & $17 \times 7$ & $-1 \times 11$ \\
CaB & $-0.17 \times 1.78$ & $-0.78 \times 0.58$ & $-0.94 \times 1.48$ & & $15 \times 5$ & $21 \times 4$ & $8 \times 5$ \\
ChB & $-0.24 \times 0.91$ & $-1.03 \times 0.41$ & $-0.76 \times 0.70$ & & $9 \times 3$ & $13 \times 7$ & $4 \times 7$ \\
BA & $1.63 \times 1.41$ & $0.64 \times 0.63$ & $-1.13 \times 1.65$ & & $12 \times 2$ & $8 \times 1$ & $-4 \times 3$ \\
MK & $2.80 \times 1.82$ & $1.97 \times 2.02$ & $-0.87 \times 1.44$ & & $9 \times 2$ & $15 \times 5$ & $7 \times 4$ \\
\hline
\end{tabular}
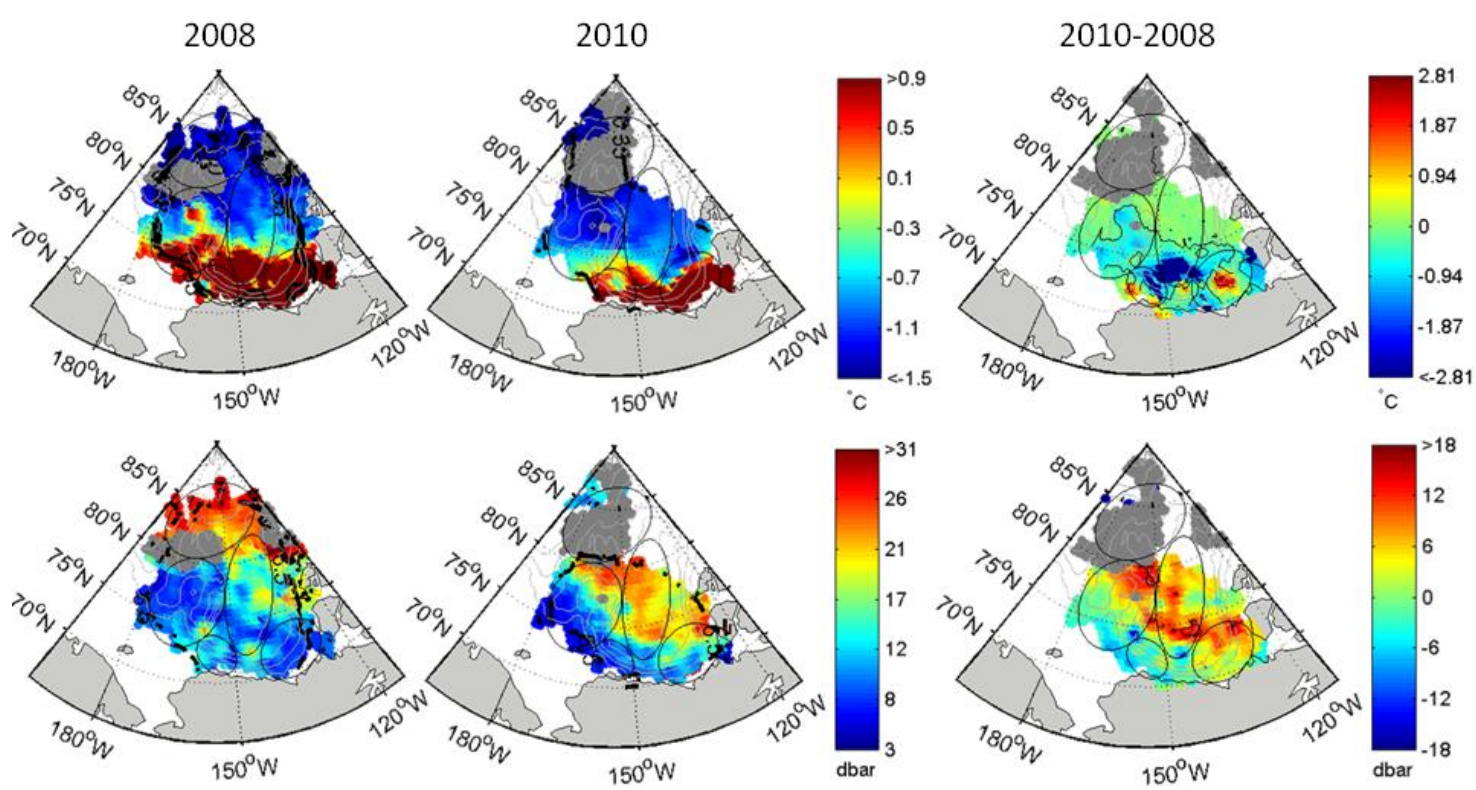

Fig. 7. Kriging interpolation of the near-surface temperature maximum (NSTM, top) and its depth level ( $Z_{\text {NSTM }}$, bottom), for years 2008 (left panel) and 2010 (middle panel), and the evolution between the two years (right panel). Grey areas correspond to the absence of the NSTM. In the left and middle panels, thick black dashed isolines correspond to estimation error $(\sigma)$ due to Kriging interpolation process. The isolines represented are $\sigma=0.35^{\circ} \mathrm{C}$ and $\sigma=7^{\circ} \mathrm{C}$ for NSTM, and $\sigma=6.5 \mathrm{dbar}$ and $\sigma=7 \mathrm{dbar}$ for $Z_{\mathrm{NSTM}}$. In the right panel, thin black isolines correspond to $95 \%$ significance.

and deepening of the NSTM from summer to fall (Jackson et al., 2010; Steele et al., 2011).

As highlighted in Sect. 3.2, sea ice conditions were very different in the southern Canadian Basin between 2008 and 2010. In agreement with Jackson et al.'s idea that sea ice concentration is a major driver of the NSTM variability, more sea ice in 2010 would result in less open water areas, and less incoming solar radiation could penetrate into the upper ocean through open water areas and/or leads to warm up the surface layers, leading to a smaller NSTM. Therefore, the strong NSTM decrease (by more than $1^{\circ} \mathrm{C}$ ) observed between 2008 and 2010 in the southern Canadian Basin most likely results in the sea ice concentration increase observed in the same region. This is due to wind forcing along the Canadian Archipelago that enhanced sea ice transport toward the Beaufort Sea and the Chukchi Sea (Stroeve et al., 2011). However, as highlighted by Stroeve et al. (2011), it is not typical of a negative AO regime to get winds driving multiyear sea ice across the Beaufort directly into the Chukchi Sea, which reminds one that the AO does not entirely explain the sea ice circulation variability and that other modes of SLP variability may intervene, like the "Dipole Anomaly" (Wu et al., 2006).

\subsection{The Pacific water}

\subsubsection{Background}

The major distinction between the upper water columns of the Canadian and Eurasian basins is related to whether or not $\mathrm{PaW}$ is present, which is an important source of freshwater 
(Woodgate and Aagaard, 2005) and nutrients (Jones and Anderson, 1986) for the Arctic Ocean. The PaW enters through the Bering Strait (Coachman and Barnes, 1961) and then transits in the Chukchi Sea for several months (Woodgate et al., 2005) before entering the deep Arctic Ocean.

The PaW is strongly affected by seasonal processes. In winter, cooling and sea ice production release brines in the water column and contribute to a colder and saltier Pacific water mass than during summertime. As a consequence, this winter Pacific water (WPaW, sometimes referred to as the winter Bering Sea water like in Coachman and Barnes, 1961) is characterized by a minimum of temperature at greater salinities and being at greater depth than the summer Pacific water $(\mathrm{SPaW})$, which is characterized by a temperature maximum at relatively low salinities (between 31 psu and 33 psu). When entering the deep Arctic basin, the SPaW and WPaW influence the upper and middle parts of the halocline, respectively (McLaughlin et al., 2004). As a result, the "double halocline structure" (Shimada et al., 2005; Shi et al., 2005) characteristic of the Canadian Basin, is different from the "cold halocline" encountered in the Eurasian Basin (Aagaard et al., 1981).

Observations led by Woodgate et al. (2010) in the Bering Strait revealed an annual mean rise of temperature of SPaW from $-0.4{ }^{\circ} \mathrm{C}$ in 2001 to $+0.4^{\circ} \mathrm{C}$ in 2007 . Other observations (Bourgain and Gascard, 2013) indicated that the SPaW was particularly warm in the Canadian Basin during the IPY compared to the previous decade.

\subsubsection{New results}

\section{The summer Pacific water}

Following Bourgain and Gascard (2013), we defined the $\mathrm{SPaW}$ as a temperature maximum deeper than $40 \mathrm{dbar}$ and above the top of the thermocline, within the salinity range 31 psu-33 psu and at least $0.16^{\circ} \mathrm{C}$ above the freezing temperature. The influence of the SPaW was then quantified by the difference between the SPaW temperature maximum and the corresponding freezing point (see Bourgain and Gascard, 2013 for further details).

Between 75 and $80^{\circ} \mathrm{N}$, the SPaW warmed up from 2008 to 2010 in the Canadian Basin: in the northern $\mathrm{CaB}$ in particular, it warmed up by more than $0.2^{\circ} \mathrm{C}$ and shoaled by 5 $10 \mathrm{dbar}$ (Table 3, Fig. 8) for which a possible explanation is proposed in Sect. 3.4.2. By contrast, in the southern Canadian Basin (southern $\mathrm{CaB}$ and $\mathrm{MK}$, corresponding to the Beaufort Sea), the SPaW cooled substantially (by $-0.49 \pm 0.30^{\circ} \mathrm{C}$ in $\mathrm{MK})$. Finally, in BA, there was a particularly strong warming of $0.35 \pm 0.42^{\circ} \mathrm{C}$ between 2008 and 2010 . Note that the SPaW could have moved back from the north-east of the MAP (Fig. 8, grey areas), but the absence of observations in 2010 in this area (see Fig. 3) precludes the use of Kriging and interpretation of interpolated fields because of the high uncertainties.

\section{The winter Pacific water}

We used the definition proposed by Pickart et al. (2005) for characterizing the WPaW: a water mass with a salinity above $32.4 \mathrm{psu}$ and a temperature below $-1.4^{\circ} \mathrm{C}$. When available, nutrients are useful tracers for this water mass, taking into account the fact that the WPaW is nutrient-rich due to a reduced biological production on the Chukchi Shelf in the wintertime (Ekwurzel et al., 2001). Silicate concentration measured during the CHINARE 2008 cruise indicated that the WPaW did not extend further north than $86^{\circ} \mathrm{N}$ (P. Coupel, personal communication, 2011). Therefore, and since we did not take into account nutrients in our WPaW index definition, we will not rely on the results of the WPaW index north of $86^{\circ} \mathrm{N}$ based on this definition.

North of $75^{\circ} \mathrm{N}$, from 2008 to 2010 , the WPaW temperature decreased significantly in the $\mathrm{CaB}$, sometimes by more than $0.05^{\circ} \mathrm{C}$, and it deepened by more than $20 \mathrm{dbar}$ (see Fig. 9). A warming of the SPaW was observed in the same area (see Sect. "The summer Pacific water"). On the contrary, in MK and south of $\mathrm{CaB}$, the WPaW warmed up while the SPaW cooled down (see Sect. "The summer Pacific water"). Such an evolution of the SPaW and WPaW temperatures between 2008 and 2010 in these regions could either be the result of the increasing/decreasing influence of the PaW, or it could be explained in terms of the water mass age. Indeed, Steele et al. (2004) suggest that the PaW temperature maximum and minimum disappear after several years of transit due to diffusion of heat. We will discuss these two possibilities in light of the observations of the freshwater evolution between 2008 and 2010 (see Sect. 4.4).

Observations also revealed that, in the vicinity of the Chukchi Sea (BA, south of ChB), both WPaW and SPaW (see Sect. "The summer Pacific water") were warmer in 2010 compared to 2008 , indicating a general warming trend of the PaW penetrating the deep Arctic Ocean since 2008. Upstream observations would be required to determine if the PaW acquired this extra heat during their transit on the Chukchi Shelf or if it captured it before.

\subsection{The freshwater content}

\subsubsection{Background}

The sources of freshwater in the Arctic Ocean are the $\mathrm{PaW}$ and the river runoff and, to a lesser degree, the sea ice meltwater and the net precipitation (Jones et al., 2008; McPhee et al., 2009), providing a total freshwater input of $8500 \mathrm{~km}^{3} \mathrm{yr}^{-1}$ with a mean residence time of about a decade (Serreze et al., 2006). About $45000 \mathrm{~km}^{3}$ of freshwater (relative to the salinity $S=34.8 \mathrm{psu}$ ), representing $60 \%$ of the total oceanic freshwater content of the Arctic Ocean, is stored in the Beaufort Gyre, an extensive anticyclonic gyre in the Canada Basin north of Alaska (Aagaard and Carmack, 1989; Serreze et al., 2006). 
Table 3. Temporal evolution of the SPaW characteristics in the five areas between 2008 and 2010.

\begin{tabular}{lrrrrrrr}
\hline & \multicolumn{3}{c}{ Temperature index $\left({ }^{\circ} \mathrm{C}\right)$} & & \multicolumn{3}{c}{ Depth (dbar) } \\
\cline { 2 - 3 } \cline { 7 - 8 } & 2008 & 2010 & $2010-2008$ & & 2008 & 2010 & $2010-2008$ \\
\hline MAP & $0.50 \times 0.06$ & $0.41 \times 0.25$ & $-0.02 \times 0.23$ & & $79 \times 7$ & $60 \times 8$ & $-17 \times 12$ \\
CaB & $0.90 \times 0.25$ & $1.13 \times 0.15$ & $0.14 \times 0.19$ & & $83 \times 9$ & $70 \times 8$ & $-12 \times 8$ \\
ChB & $0.84 \times 0.25$ & $1.02 \times 0.21$ & $0.18 \times 0.17$ & & $60 \times 16$ & $59 \times 8$ & $-1 \times 16$ \\
BA & $0.92 \times 0.21$ & $1.30 \times 0.23$ & $0.35 \times 0.42$ & & $55 \times 6$ & $74 \times 3$ & $18 \times 5$ \\
MK & $1.08 \times 0.13$ & $0.59 \times 0.35$ & $-0.49 \times 0.30$ & & $75 \times 12$ & $61 \times 13$ & $-13 \times 3$ \\
\hline
\end{tabular}

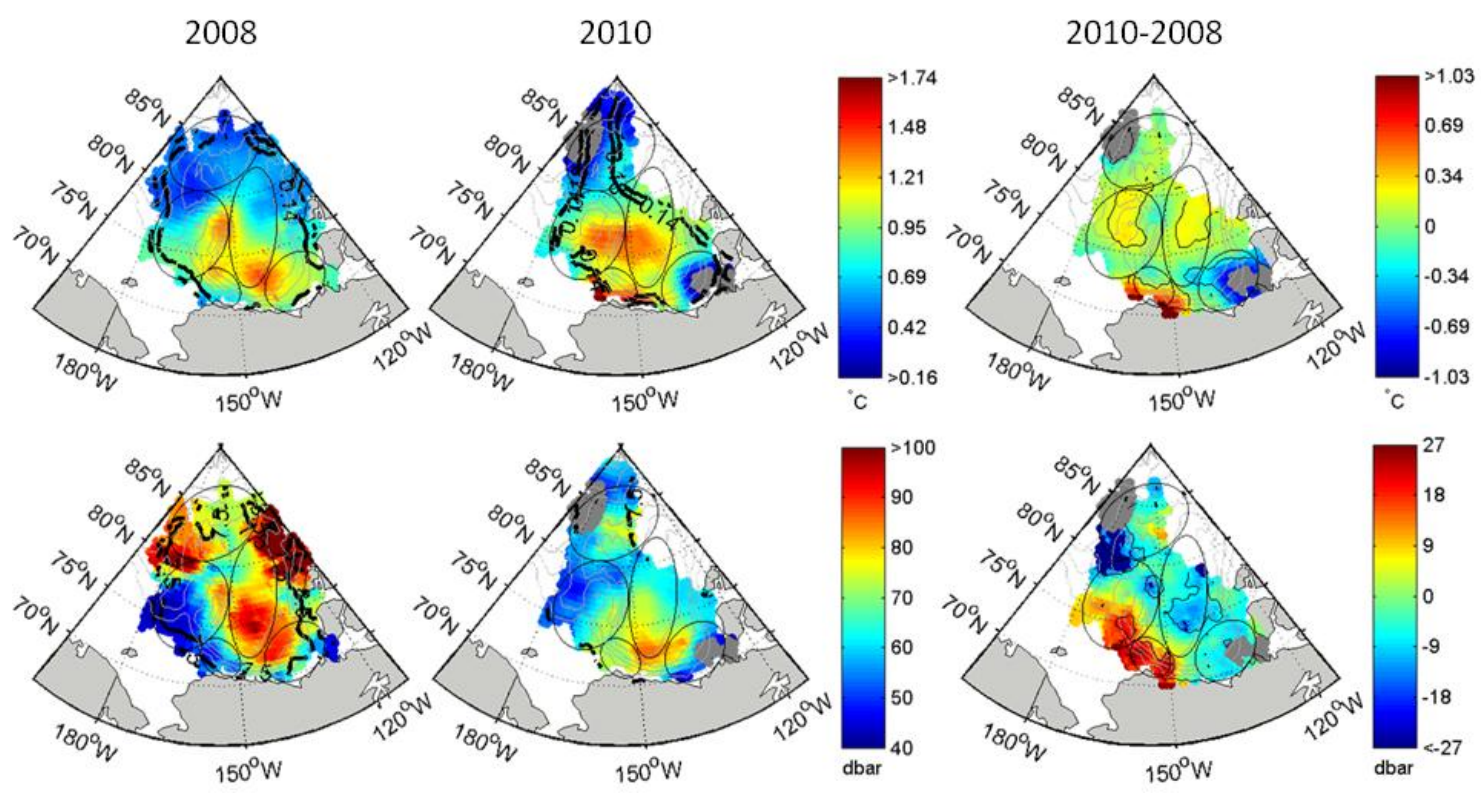

Fig. 8. Kriging interpolation of the $\mathrm{SPaW}$ index, $T_{\mathrm{SPaW}}-T_{\mathrm{FP}}$ (top), and its depth level $\left(Z_{\mathrm{SPaW}}\right.$, bottom), for years 2008 (left panel) and 2010 (middle panel), and the evolution between the two years (right panel). Grey areas correspond to the absence of the SPaW. In the left and middle panels, thick black dashed isolines correspond to estimation error $(\sigma)$ due to Kriging interpolation process. The isolines represented are $\sigma=0.14^{\circ} \mathrm{C}$ and $\sigma=0.18^{\circ} \mathrm{C}$ for $\mathrm{SPaW}$ index, and $\sigma=7.5 \mathrm{dbar}$ and $\sigma=8.5 \mathrm{dbar}$ for $Z_{\mathrm{SPaW}}$. In the right panel, thin black isolines correspond to $95 \%$ significance.

Recent observations indicated a substantial freshening in the Canada and Makarov basins (Mc Phee et al., 2009; Rabe et al., 2011). Proshutinsky et al. (2009) estimated the freshwater content positive trend to be $178 \mathrm{~cm} \mathrm{yr}^{-1}$ (when calculated with $S=34.8$ psu as the reference salinity) south of $80^{\circ} \mathrm{N}$ for the 2003-2007 time period. Bourgain and Gascard (2011) observed an intensification of the surface salinity freshening in 2007-2008. The strength of the Beaufort Gyre (Giles et al., 2012) and the Siberian River runoff pathways (Morison et al., 2012) have a major influence on the freshwater content variability. Indeed, though Mackenzie River input was identified in the Canada Basin (Yamamoto-Kawai et al., 2009), the Siberian River runoff is the largest fluvial component of this basin (Guay et al., 2009). In addition, the increasing role of sea ice meltwater was also identified in the Canada Basin (Yamamoto-Kawai et al., 2009).

\subsubsection{New results}

Following Rabe et al. (2011), we used the following definition to obtain the inventory of liquid freshwater $H_{\mathrm{FW}}$ between the surface and the 34 isohaline depth (as the lower boundary of the integral):

$H_{\mathrm{FW}}=\int\left(S_{\mathrm{ref}}-S\right) / S_{\mathrm{ref}} \mathrm{d} z$

where $S$, the observed salinity, and $S_{\text {ref }}$, the relative salinity with $S_{\mathrm{ref}}=35 \mathrm{psu}$. $H_{\mathrm{FW}}$ is given in meters.

For both years (2008 and 2010), the maximum of $H_{\mathrm{FW}}$ was located in the Beaufort Sea (Fig. 10). This was due to the persistent anticyclonic wind pattern, leading to Ekman pumping and an accumulation of freshwater in the Beaufort Gyre. In addition, there was a gradual decline of $H_{\mathrm{FW}}$ from the Beaufort Sea toward the Siberian shelf seas and toward North Pole during both years (see Table 5). Our results for 2008 are in good agreement with the observations 
Table 4. Temporal evolution of the WPaW characteristics in the five areas between 2008 and 2010.

\begin{tabular}{lrrrrrrr}
\hline & \multicolumn{3}{c}{ Temperature $\left({ }^{\circ} \mathrm{C}\right)$} & & \multicolumn{3}{c}{ Depth (dbar) } \\
\cline { 2 - 3 } \cline { 6 - 8 } & 2008 & 2010 & $2010-2008$ & & 2008 & 2010 & $2010-2008$ \\
\hline MAP & $-1.51 \times 0.04$ & $-1.54 \times 0.04$ & $-0.01 \times 0.03$ & & $111 \times 23$ & $85 \times 25$ & $-11 \times 30$ \\
CaB & $-1.48 \times 0.06$ & $-1.54 \times 0.03$ & $-0.04 \times 0.07$ & & $162 \times 23$ & $181 \times 12$ & $14 \times 16$ \\
ChB & $-1.58 \times 0.03$ & $-1.56 \times 0.03$ & $0.02 \times 0.04$ & & $145 \times 23$ & $165 \times 19$ & $20 \times 11$ \\
BA & $-1.58 \times 0.03$ & $-1.51 \times 0.03$ & $0.06 \times 0.02$ & & $149 \times 15$ & $174 \times 7$ & $22 \times 17$ \\
MK & $-1.49 \times 0.02$ & $-1.42 \times 0.02$ & $0.06 \times 0.03$ & & $156 \times 21$ & $147 \times 18$ & $-8 \times 12$ \\
\hline
\end{tabular}
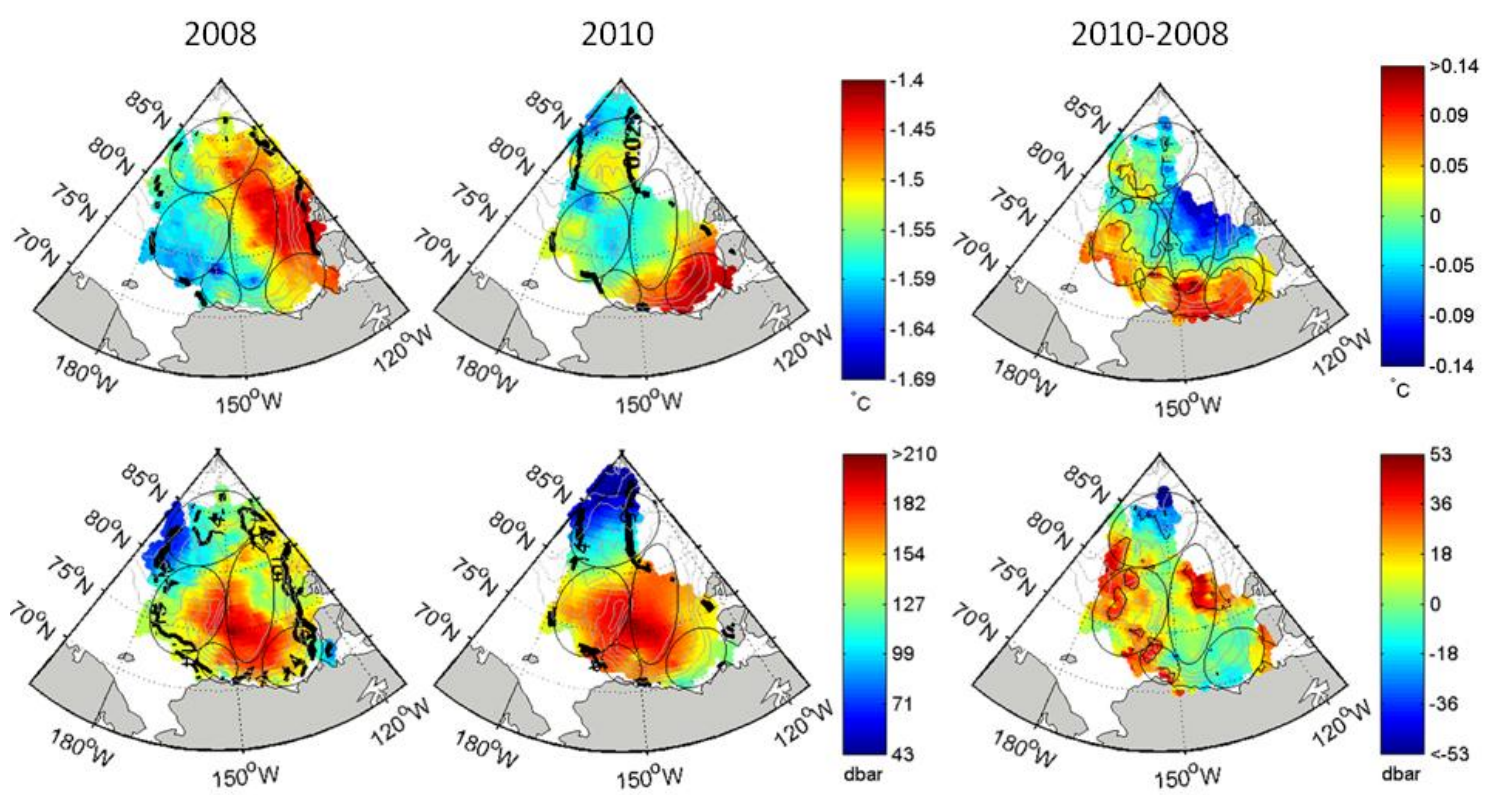

Fig. 9. Kriging interpolation of the WPaW temperature ( $T_{\mathrm{WPaW}}$, top) and the depth level ( $Z_{\mathrm{WPaW}}$, bottom), for years 2008 (left panel) and 2010 (middle panel), and the evolution between the two years (right panel). In the left and middle panels, thick black dashed isolines correspond to estimation error $(\sigma)$ due to Kriging interpolation process. The isolines represented are $\sigma=0.021^{\circ} \mathrm{C}$ and $\sigma=0.025^{\circ} \mathrm{C}$ for $T_{\mathrm{WPaW}}$, and $\sigma=14 \mathrm{dbar}$ and $\sigma=15 \mathrm{dbar}$ for $Z_{\mathrm{WPaW}}$. I $\mathrm{n}$ the right panel, thin black isolines correspond to $95 \%$ significance.

of Rabe and Wisotzki (2010) for the 2006-2008 time period with $H_{\mathrm{FW}}$ reaching more than $25 \mathrm{~m}$ in the Beaufort Gyre and minimum values (between $6 \mathrm{~m}$ and $13 \mathrm{~m}$ ) encountered in the western MAP.

We estimated that $H_{\mathrm{FW}}$ increased in the $\mathrm{CaB}$ by $2.70 \pm 3.19 \mathrm{~m}$ between 2008 and 2010 (Table 5). Observations by Proshutinsky et al. (2010) indicate that the $H_{\mathrm{FW}}$ increase in $\mathrm{ChB}$ occurred from 2009. In the southern regions, $H_{\mathrm{FW}}$ decreased by $2.76 \pm 1.50 \mathrm{~m}$ in $\mathrm{MK}$ and increased by $4.08 \pm 1.84 \mathrm{~m}$ in BA from 2008 to 2010 . Northward, in the MAP, $H_{\mathrm{FW}}$ decreased by $2.18 \pm 3.53 \mathrm{~m}$ on average but the high standard deviation indicates large spatial heterogeneity within this region, and Fig. 9 suggests that the decrease may be much stronger in the northern MAP. When calculating the evolution of the liquid freshwater content (as the sum of $H_{\mathrm{FW}} \times$ surface in each point of the grid) in the five different regions from 2008 to 2010, we found a decrease of $410 \mathrm{~km}^{3}$ in the MAP and an increase of $850 \mathrm{~km}^{3}$ in the CaB.
In the shallow regions, we obtain an increase of $360 \mathrm{~km}^{3}$ and $410 \mathrm{~km}^{3}$ in the $\mathrm{ChB}$ and BA, respectively, and a decrease of $650 \mathrm{~km}^{3}$ in the MK.

Compared to previous years, our results suggested that the southern Canadian Basin kept accumulating freshwater between 2008 and 2010 (except in MK) while the northern Canadian Basin underwent a small decrease in its liquid freshwater inventory following a strong surface waters freshening during IPY years (Bourgain and Gascard, 2011).

Proshutinsky et al. $(2002,2009)$ and Condron et al. (2008) have shown that decadal variations of the freshwater content in the Beaufort Gyre were associated with changes in atmospheric forcing. When anticyclonic wind conditions prevail, the freshwater content increases in the Beaufort Gyre as a result of the enhanced wind-generated Ekman pumping, and vice-versa (see Fig. 11). Therefore, the strong anticyclonic wind conditions characterizing summer 2010 are more likely 

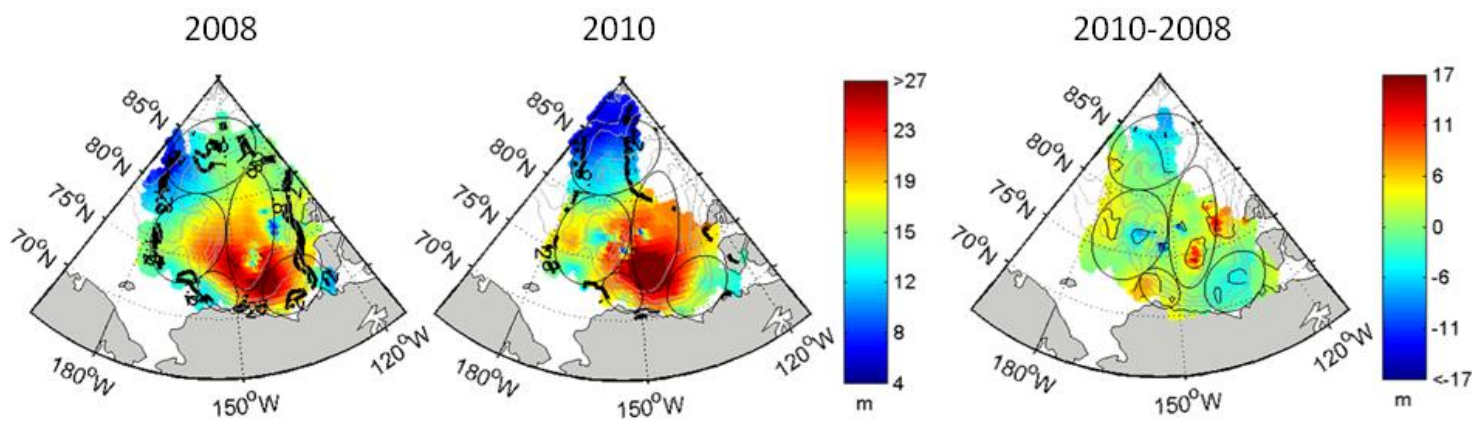

Fig. 10. Kriging interpolation of $H_{\mathrm{FW}}$, the liquid freshwater content, for years 2008 (left panel) and 2010 (middle panel), and the evolution between the two years (right panel). In the left and middle panels, thick black dashed isolines correspond to estimation error $(\sigma)$ due to Kriging interpolation process. The isolines represented are $\sigma=1.8 \mathrm{~m}$ and $\sigma=2 \mathrm{~m}$. In the right panel, thin black isolines correspond to $95 \%$ significance.

Table 5. Temporal evolution of the $H_{\mathrm{FW}}(\mathrm{m})$ in the five areas between 2008 and 2010.

\begin{tabular}{lrrr}
\hline & 2008 & 2010 & $2010-2008$ \\
\hline MAP & $13.26 \times 2.87$ & $9.56 \times 2.41$ & $-2.18 \times 3.53$ \\
CaB & $20.06 \times 3.41$ & $23.54 \times 3.29$ & $2.70 \times 3.19$ \\
ChB & $17.00 \times 3.03$ & $17.87 \times 2.74$ & $0.84 \times 2.85$ \\
BA & $16.20 \times 3.38$ & $20.72 \times 2.33$ & $4.08 \times 1.84$ \\
MK & $21.22 \times 3.86$ & $18.39 \times 3.54$ & $-2.76 \times 1.50$ \\
\hline
\end{tabular}

responsible for the observed freshwater content increase of $850 \mathrm{~km}^{3}$ in the $\mathrm{CaB}$ between 2008 and 2010.

Steele et al. (2004) proposed that during negative AO phases, one of the main sources of freshwater, the PaW, strongly recirculates within the Beaufort Gyre. As a consequence, the extreme increase in atmospheric anticyclonicity in 2010 , characterized by a smaller transport in the Transpolar Drift (61\% less) than climatology and a strong Beaufort Sea High (Stroeve et al., 2011), most likely explains why there is more $\mathrm{PaW}$ between 75 and $80^{\circ} \mathrm{N}$ in $\mathrm{CaB}$ (see Sect. 4.2.2), which as a result contributes to the freshwater content increase observed in this region.

In contrast, south of $75^{\circ} \mathrm{N}$, the $\mathrm{PaW}$ signature decreased (the SPaW/WPaW temperature decreased/increased) between 2008 and 2010 while the freshwater content increased. This suggests two possibilities: either there was a smaller amount of PaW in 2010 than in 2008, with other freshwater sources intervening in the freshwater content increase, or, on the contrary, the PaW was present in a larger amount but it was older, explaining that the $\mathrm{PaW}$ signature decreased due to diffusion of heat with time, as suggested by Steele et al. (2004).

The reduced freshening of the northern part of MAP may be explained in terms of decreasing Siberian River runoff input (see Fig. 11) in response of the atmospheric forcing (Johnson and Polyakov, 2001; Morison et al., 2012) with cyclonic/anticyclonic conditions driving the Siberian River runoff toward the Makarov/Amundsen basins. Indeed, in 2007-2008, when cyclonic conditions prevailed, a larger influence of the Siberian River runoff in the Makarov Basin relative to the Amundsen Basin was observed (Alkire et al., 2010) inducing a strong freshening of the Makarov Basin (Bourgain and Gascard, 2011). In opposite, the strong anticyclonic forcing observed in 2010 may have driven the river runoff toward the Amundsen Basin rather than toward the Makarov Basin and the northern Canadian Basin, explaining the surface freshening observed in 2010 in the Eurasian Basin by Timmermans et al. (2011), and the reduced freshening of the northern part of MAP observed in Fig. 10.

\section{Conclusions}

We investigated the large-scale changes of the Canadian Basin water column based on summertime observations from 2008 and 2010 at a time of strong AO inversion.

Subsequent to a positive AO index in 2008, the extremely low AO index of 2010 was associated with a sharp increase in atmospheric anticyclonicity and was responsible for the large-scale freshwater content change observed in the Canadian Basin. North of $80^{\circ} \mathrm{N}$, anticyclonic winds driving the Siberian River runoff toward the Eurasian Basin induced less freshening in the northern Mendeleyev Abyssal Plain in 2010 , in contrast with IPY year 2008, characterized by more cyclonic conditions and strong surface waters freshening in that region. Conversely, south of $80^{\circ} \mathrm{N}$, in the Beaufort Gyre $(\mathrm{CaB})$, the freshwater content increased by up to $850 \mathrm{~km}^{3}$ between 2008 and 2010, more likely due to enhanced windgenerated Ekman pumping because of the increased anticyclonicity.

Following a positive trend of $+0.13^{\circ} \mathrm{C} \mathrm{yr}^{-1}$ observed from 2004 to 2007 in the Canada Basin (Jackson et al., 2010), the NSTM decreased by almost $1{ }^{\circ} \mathrm{C}$ south of $75^{\circ} \mathrm{N}$ between 2008 and 2010, more likely due to a surface albedo feedback related to a sea ice concentration increase in the Beaufort Sea from 2008 to 2010. 


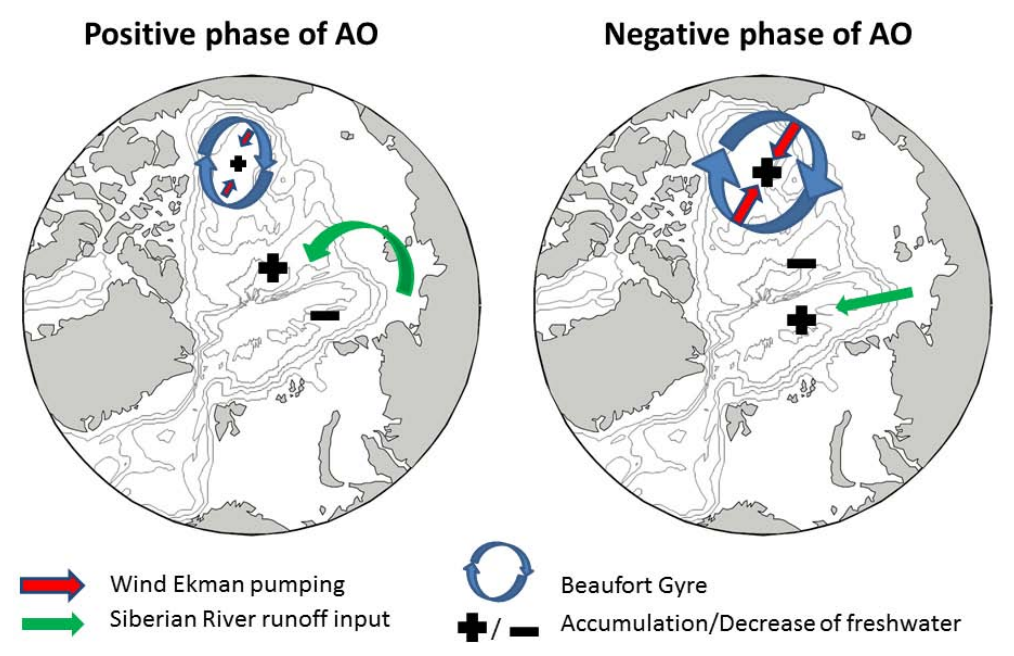

Fig. 11. Scheme of the freshwater circulation during a negative phase of the AO (right) and a positive phase of the AO (left), derived from Steele and Boyd (1998), Johnson and Polyakov (2001), Proshutinsky et al. (2002, 2009), Condron et al. (2008), and Morison et al. (2012). During an anticyclonic regime (negative phase of AO), the Beaufort Gyre anticyclonic circulation is enhanced and Ekman pumping is very strong as a result. Therefore, a large amount of freshwater accumulates at the center of the Beaufort Gyre. In addition, the Siberian River runoff is diverted directly towards the Eurasian Basin. Conversely, during a cyclonic regime (positive phase of the AO), the Beaufort Gyre is weaker than during an anticyclonic regime: Ekman pumping is reduced and less freshwater accumulates. The Siberian River runoff is diverted by eastward winds towards the Makarov Basin rather than towards the Eurasian Basin. As a result, there is an accumulation of freshwater in the Makarov Basin and a deficit of freshwater in the Eurasian Basin.

In the Canada Basin, the PaW evidenced different behaviour south and north of $75^{\circ} \mathrm{N}$ between 2008 and 2010 . From 2008 to 2010, and between 75 and $80^{\circ} \mathrm{N}$, the $\mathrm{PaW}$ influence increased (The SPaW warmed up and the WPaW cooled down) possibly due to the strong recirculation within the Beaufort Gyre related to a negative AO index phase, i.e. high anticyclonicity, as proposed by Steele et al. (2004). In contrast, south of $75^{\circ} \mathrm{N}$, in the Mackenzie River region, the SPaW cooled down and the WPaW warmed up from 2008 to 2010. This suggests that either the PaW was less present in 2010 than in 2008 in this region, and/or the PaW was older in 2010 than in 2008 due to a different circulation scheme, increasing the path length between the source (Bering Strait) and the study area. As a result, the summer and winter temperature signatures of the PaW decreased due to dissipation of heat with time, as suggested by Steele et al. (2004). In regions located in the vicinity of the Chukchi Sea (BA, southern $\mathrm{ChB}$ ), the PaW (both Summer and Winter waters) warmed up significantly, indicating a general warming trend of the PaW entering in the deep Arctic Ocean since 2008. Upstream observations would be needed to determine if this extra heat was carried out from Bering Strait as partly suggested by Woodgate et al. (2010) up to 2008, and/or acquired when transiting across the Chukchi Shelf.

The response of the Atlantic water, located deeper in the Canadian Basin water column, to the 2010 AO index lowest record, is also expected in the future. Indeed, the Atlantic water masses are in direct contact with the atmosphere in the Northern Atlantic region. Because of long time transport
(Morison et al., 2006) from this region to the Canadian Basin, major changes in the Atlantic water mass of the Canadian Basin are delayed for a few years in response to the $2010 \mathrm{AO}$ index lowest record.

\section{Appendix A}

\section{List of acronyms}

\begin{tabular}{ll}
\hline ChB: & Chukchi Borderland \\
CAP: & Chukchi Abyssal Plain \\
CP: & Chukchi Plateau \\
NR: & Northwind Ridge \\
BA: & Barrow Canyon \\
MK: & Mackenzie River \\
CaB: & Canada Basin \\
MAP: & Mendeleyev Abyssal Plain \\
MaB: & Makarov Basin \\
AR: & Alpha Ridge \\
MR: & Mendeleyev Ridge \\
NSTM: & near-surface temperature maximum \\
PaW: & Pacific water \\
SPaW: & summer Pacific water \\
WPaW: & winter Pacific water \\
$H_{\text {FW: }}$ & liquid freshwater \\
AT925: & Air temperature at 925 dbar \\
\hline
\end{tabular}


Acknowledgements. We express our gratitude to the captain and the crew of the Xuelong icebreaker for the opportunity to take part in the field work in the Arctic Ocean. We thank the Second Institute of Oceanography SOA/PRC (State Oceanic Administration, China, Hangzhou) for inviting the French scientists from the LOCEAN laboratory (UPMC-University Pierre et Marie Curie) to participate to the CHINARE cruise. The ice-tethered profiler data were collected and made available by the ice-tethered profiler Program based at the Woods Hole Oceanographic Institution (http://www.whoi.edu/itp). Polarstern data, first analysed by Rabe and Wisotzki (2010), come from the DAMOCLES Project, financed by the European Union in the 6th Framework Programme for Research and Development. We are grateful to Sarah Zimmerman for the LSSL data. The atmospheric data for this study are from the Research Data Archive (RDA), which is maintained by the Computational and Information Systems Laboratory (CISL) at the National Center for Atmospheric Research (NCAR). NCAR is sponsored by the National Science Foundation (NSF). We are grateful to Spreen et al. (2008) for the availability of the AMSR-E data. We thank Pierre Coupel for helpful discussion. We are very grateful to the Geovariances company for advice and help about the Kriging interpolation theory and process on ISATIS software. The Ph.D. was supported by the AXA Research Fund. The authors would like to thank the editor and anonymous reviewers for their insightful comments, which greatly improved the paper.

Edited by: H. Eicken

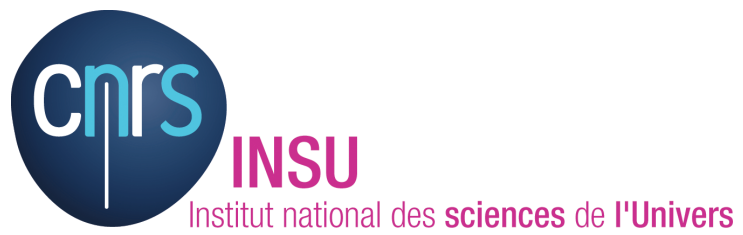

The publication of this article is financed by CNRS-INSU.

\section{References}

Aagaard, K. and Carmack, E. C.: The Role of Sea Ice and Other Fresh Water in the Arctic Circulation, J. Geophys. Res., 94, 14485-14498, doi:10.1029/JC094iC10p14485, 1989.

Aagaard, K., Coachman, L. K., and Carmack, E.: On the halocline of the Arctic Ocean, Deep Sea Res., 28, 529-545, doi:10.1016/0198-0149(81)90115-1, 1981.

Alkire, M. B., Falkner, K. K., Morison, J., Collier, R. W., Guay, C. K., Desiderio, R. A., Rigor, I., and McPhee, M.: Sensor-based profiles of the NO parameter in the central Arctic and southern Canada Basin: New insights regarding the cold halocline, DeepSea Res. Pt. I, 57, 1432-1443, doi:10.1016/j.dsr.2010.07.011, 2010.

Bourgain, P. and Gascard, J. C.: The Arctic Ocean halocline and its interannual variability from 1997 to 2008 , Deep-Sea Res. Pt. I, 58, 745-756, doi:10.1016/j.dsr.2011.05.001, 2011.

Bourgain, P. and Gascard, J. C: The Atlantic and Summer Pacific waters variability in the Arctic Ocean from 1997 to 2008, Geophys. Res. Lett, 39, doi:10.1029/2012GL051045, 2012.
Coachman, L. K. and Barnes, C. A.: The contribution of Bering Sea Water to the Arctic Ocean, Arctic, 14, 146-161, 1961.

Condron, A., Winsor, P., Hill, C., and Menemenlis, D.: Simulated Response of the Arctic Freshwater Budget to Extreme NAO Wind Forcing, J. Climate, 22, 2422-2437, doi:10.1175/2008JCLI2626.1, 2008.

Dickson, R. R., Osborne, T. J., Hurrell, J. W., Meincke, J., Blindheim, J., Adlandsvik, B., Vinje, T., Alekseev, G., and Maslowski, W.: The Arctic Ocean Response to the North Atlantic Oscillation, J. Climate, 13, 2671-2696, 2000.

Ekwurzel, B., Schlosser, P., Mortlock, R. A., and Fairbanks, R. G.: River runoff, sea ice meltwater, and Pacific water distribution and mean residence times in the Arctic Ocean, J.Geophys. Res., 106, 9075-9092, 2001.

Fofonoff, N. and Millard Jr., R.: Algorithms for computation of fundamental properties of seawater, Tech. rep., Unesco/SCOR/IAPSO Joint Panel on Oceanographic Tables and Standards and SCOR Working Group 51, 1983.

Gerdes, R., Karcher, M., Köberle, C., and Fieg, K.: Simulating the long term variability of liquid freshwater export from the Arctic Ocean, Arctic-Subarctic Ocean Fluxes: Defining the role of the Northern Seas in Climate, edited by: Dickson, B., Meincke, J., and Rhines, P., Springer, ISBN: 978-1-4020-6773-0, 2008.

Giles, K. A., Laxon, S. W., Ridout, A. L., Wingham, D. J., and Bacon, S.: Western Arctic Ocean freshwater storage increased by wind-driven spin-up of the Beaufort Gyre, Nature, NGEO1379, doi:10.1038/NGEO1379, published online on 22 January 2012.

Guay, C. K. H., McLaughlin, F. A., and Yamamoto-Kawai, M.: Differentiating fluvial components of upper Canada Basin waters on the basis of measurements of dissolved barium combined with other physical and chemical tracers, J. Geophys. Res., 114, C00A09, doi:10.1029/2008JC005099, 2009.

Jackson, J. M., Carmack, E. C., McLaughlin, F. A., Allen, S. E., and Ingram, R. G.: Identification, characterization, and change of the near-surface temperature maximum in the Canada Basin, 19932008, J. Geophys. Res., 115, 5021, doi:10.1029/2009JC005265, 2010.

Jackson, J. M., Williams, W. J., and Carmack, E. C.: Winter sea-ice melt in the Canada Basin, Arctic Ocean, Geophys. Res. Lett., 39, L03603, doi:10.1029/2011GL050219, 2012.

Johnson, M. A. and Polyakov, I. V.: The Laptev Sea as a source for recent Arctic Ocean salinity changes, Geophys. Res. Lett., 28, 2017-2020, 2001.

Jones, E. P. and Anderson, L. G.: On the origin of the chemical properties of the Arctic Ocean halocline, J. Geophys. Res., 91, 10759-10767, 1986.

Jones, E. P., Anderson, L. G., Jutterström, S., Mintrop, L., and Swift, J. H.: Pacific freshwater, river water and sea ice meltwater across Arctic Ocean basins: Results from the 2005 Beringia Expedition, J. Geophys. Res., 113, 1-10, doi:10.1029/2007JC004124, 2008.

Kalnay, E., Kanamitsu, M., Kistler, R., Collins, W., Deaven, D., Gandin, L., Iredell, M., Saha, S., White, G., Woolen, J., Zhu, Y., Chelliah, M., Ebisuzaki, W., Higgins, W., Janowiak, J., Mo, K. C., Ropelewski, C., Wang, J., Leetmaa, A., Reynolds, R., Jenne, R., and Joseph, D.: The NCEP/NCAR reanalysis 40-year project, B. Am. Meteorol. Soc., 77, 437-471, 10.1175/15200477(1996)077<0437:TNYRP>2.0.CO;2, 1996. 
Krige, D. G.: Une approche statistique à quelques évaluations de mine et problèmes alliés chez le Witwatersrand, Thèse principale de l'université de Witwatersrand, 1951.

Kwok, R.: Recent changes in Arctic Ocean sea ice motion associated with the North Atlantic Oscillation, Geophys. Res. Lett., 27, 775-778, 2000.

Matheron, G.: Principes de geostatistics, Econ. Geol., 58, 12461266, 1963.

McLaughlin, F. A., Carmack, E. C., Macdonald, R. W., Melling, H., Swift, J. H., Wheeler, P. A., Sherr, B. F., and Sherr, E. B.: The joint roles of Pacific and Atlantic origin waters in the Canada basin 1997-1998, Deep Sea Res. I, 51, 107-128, doi:10.1016/j.dsr.2003.09.010, 2004.

McPhee, M. G., Proshutinsky, A., Morison, J. H., Steele, M., and Alkire, B.: Rapid change in freshwater content of the Arctic Ocean, Geophys. Res. Lett., 36, L10602, doi:10.1029/2009GL037525, 2009.

Morison, J., Steele, M., Kikuchi, T., Falkner, K., and Smethie, W.: Relaxation of central Arctic Ocean hydrography to pre-1990s climatology, Geophys. Res. Lett., 33, L17604, doi:10.1029/2006GL026826, 2006.

Morison, J. H., Kwok, R., Peralta-Ferriz, C., Alkire, M., Rigor, I., Andersen, R., and Steele, M.: Changing Arctic Ocean freshwater pathways, Nature, 481, 66-70, doi:10.1038/nature10705, 2012.

Pickart, R. S., Weingartner, T. J., Pratt, L. J., Zimmermann, S., and Torres, D. J.: Flow of winter-transformed Pacific water into the Western Arctic, Deep-Sea Res. Pt. II, 52, 3175-3198, doi:10.1016/j.dsr2.2005.10.009, 2005.

Proshutinsky, A. Y. and Johnson, M. A.: Two circulation regimes of the wind-driven Arctic Ocean, J. Geophys. Res., 102, 1249312514, 1997.

Proshutinsky, A., Bourke, R. H., and McLaughlin, F. A.: The role of the Beaufort Gyre in Arctic climate variability: Seasonal to decadal climate scales, Geophys. Res. Lett., 29, 2100, doi:10.1029/2002GL015847, 2002.

Proshutinsky, A., Krishfield, R., Timmermans, M.-L., Toole, J., Carmack, E., McLaughlin, F., Williams, W. J., Zimmermann, S., Itoh, M., and Shimada, K.: Beaufort Gyre freshwater reservoir: state and variability from observation, J. Geophys. Res., 114, C00A10, doi:10.1029/2008JC005104, 2009.

Proshutinsky, A., Timmermans, M. L., Ashik, I., BeszczynskaMoeller, A., Carmack, E., Frolov, I., Krishfield, R., McLaughlin, F., Morison, J., Polyakov, I., Shimada, K., Sokolov, V., Steele, M., Toole, J., and Woodgate, R.: Ocean [in Arctic Report Card 2010], http://www.arctic.noaa.gov/reportcard, 2010.

Rabe, B. and Wisotzki, A.: Physical oceanography during Polarstern cruise ARK-XXIII/3 (AMEX I), Alfred Wegener Institute for Polar and Marine Research, Bremerhaven, doi:10.1594/PANGAEA.733425, 2010.

Rabe, B., Karcher, M., Schauer, U., Toole, J .M., Krishfield, R. A., Pisarev, S., Kauker, F., Gerdes, R., and Kikuchi, T.: An assessment of Arctic Ocean freshwater content changes from the 1990s to the 2006-2008 period, Deep-Sea Res. Pt. I 58, 173185, doi:10.1016/j.dsr.2010.12.002, 2011.

Rigor, I. and Wallace, J.: Variations in the age of arctic sea-ice and summer sea-ice extent, Geophys. Res. Lett., 31, L09401, doi:10.1029/2004GL019492, 2004.

Rigor, I. G., Wallace, J. M., and Colony, R. L.: Response of sea ice to the Arctic Oscillation, J. Climate, 15, 2648-2663, 2002.
Serreze, M. C., Barrett, A. P., Slater, A. G., Woodgate, R., Aagaard, K., Lammers, R. B., Steele, M., Moritz, R., Meredith, M., and Less, C. M.: The large-scale freshwater cycle of the Arctic, J. Geophys. Res., 111, C11010, doi:10.1029/2005JC003424, 2006.

Shi, J., Zhao, J., Li, S., Cao, Y., and Qu, P.: A double-halocline structure in the Canada Basin of the Arctic Ocean, Acta Oceanol. Sin., 24, 25-35, 2005.

Shimada, K., Itoh, M., Nishino, S., McLaughlin, F., Carmack, E., and Proshutinsky, A.: Halocline structure in the Canada basin of the Arctic Ocean, Geophys. Res. Lett., 32, L03605, doi:10.1029/2004GL021358, 2005.

Shimada, K., Kamoshida, T., Itoh, M., Nishino, S., Carmack, E., McLaughlin, F. A., Zimmermann, S., and Proshutinsky, A.: Pacific Ocean inflow: Influence on catastrophic reduction of sea ice cover in the Arctic Ocean, Geophys. Res. Lett., 33, L08605, doi:10.1029/2005GL025624, 2006.

Spreen, G., Kaleschke, L., and Heygster, G.: Sea ice remote sensing using AMSR-E $89 \mathrm{GHz}$ channels, J. Geophys. Res., 113, C02S03, doi:10.1029/2005JC003384, 2008.

Steele, M. and Boyd, T.: Retreat of the cold halocline layer in the Arctic Ocean, J. Geophys. Res., 103, 10419-10435, 1998.

Steele, M., Morison, J., Ermold, W., Rigor, E., and Ortmeyer, M.: Circulation of summer Pacific halocline water in the Arctic Ocean, J. Geophys. Res., 109, C02027, doi:10.1029/2003JC002009, 2004.

Steele, M., Ermold, W., and Zhang, J.: Modeling the formation and fate of the near-surface temperature maximum in the Canadian Basin of the Arctic Ocean, J. Geophys. Res., 116, C11015, doi:10.1029/2010JC006803, 2011.

Stroeve, J. C., Maslanik, J., Serreze, M. C., Rigor, I., Meier, W., and Fowler, C.: Sea ice response to an extreme negative phase of the Arctic Oscillation during winter 2009/2010, Geophys. Res. Lett., 38, L02502, doi:10.1007/s10584-011-0101-1, 2011.

Thompson, D. W. J. and Wallace, J. M.: The Arctic Oscillation signature in the wintertime geopotential height and temperature fields, Geophys. Res. Lett., 25, 1297-1300, 1998.

Timmermans, M.-L., Proshutinsky, A., Krishfield, R. A., Perovich, D. K., Richter-Menge, J. A., Stanton, T. P., and Toole, J. M.: Surface freshening in the Arctic Ocean's Eurasian Basin: An apparent consequence of recent change in the wind-driven circulation, J. Geophys. Res., 116, C00D03, doi:10.1029/2011JC006975, 2011.

Toole, J. M., Timmermans, M. L., Perovich, D. K., Krishfield, R. A., Proshutinsky, A., and Richter-Menge, J. A.: Influences of the Ocean Surface Mixed layer and thermohaline stratification on Arctic Sea Ice in the Central Canada basin, J. Geophys. Res., 115, C10018, doi:10.1029/2009JC005660, 2010.

Woodgate, R. A. and Aagaard, K.: Revising the Bering Strait freshwater flux into the Arctic Ocean, Geophys. Res. Lett., 32, L02602, doi:10.1029/2004GL021747, 2005.

Woodgate, R. A., Aagaard, K., and Weingartner, T. J.: A year in the physical oceanography of the Chukchi Sea: Moored measurements from autumn 1990-1991, Deep Sea Res. II, 52, 31163149, doi:10.1016/j.dsr2.2005.10.016, 2005.

Woodgate, R. A., Weingartner, T. J., and Lindsay, R.: The 2007 Bering Strait oceanic heat flux and anomalous Arctic sea ice retreat, Geophys. Res. Lett., 37, L01602, doi:10.1029/2009GL041621, 2010. 
Wu, B., Wang, J., and Walsh, J.: Dipole anomaly in the winter arctic atmosphere and its association with sea ice motion, J. Climate, 19, 210-225, 2006.
Yamamoto-Kawai, M., McLaughlin, F. A., Carmack, E. C., Nishino, S., Shimada, K., and Kurita, N.: Surface freshening of the Canada Basin, 2003-2007: River runoff versus sea ice meltwater, J. Geophys. Res., 114, C00A05, doi:10.1029/2008JC005000, 2009. 